\title{
Wastefree purification method for potassium brine used in industrial elec- trochemical processes
}

\author{
Bożenna Pisarska, Mariusz Nowak \\ Institute of Inorganic Chemistry, ul. Sowińskiego 11, 44-101 Gliwice, Poland, e-mail: pisarska@ichn.gliwice.pl
}

\begin{abstract}
A new concept is presented for purifying potassium brine ( $\mathrm{KCl}$ solution) obtained from technical-grade potassium chloride. This concept is based on the hydroxide/carbonate method of removing ions of alkaline earth metals and on separating $\mathrm{SO}_{4}{ }^{2-}$ ions by means of zirconyl anion exchanger. The purification process provides the following products: purified potassium brine suitable for the manufacture of $\mathrm{KClO}_{3}$ or for further purification and subsequent manufacture of $\mathrm{KOH}, \mathrm{Cl}_{2}$ and $\mathrm{H}_{2}$ using membrane cell technology, magnesium and potassium containing agricultural lime (chalk) suitable for neutralizing soil acidity and enriching soil with magnesium and potassium, and technical-grade potassium sulphate containing 99.0 to $99.8 \% \mathrm{~K}_{2} \mathrm{SO}_{4}$.
\end{abstract}

Keywords: potassium brine, purification processes, wastefree processes.

\section{INTRODUCTION}

Naturally occurring potassium chloride (the mineral sylvite) or that obtained from complex natural salts (e.g. carnallite $\mathrm{KCl} \cdot \mathrm{MgCl}_{2} \cdot 6 \mathrm{H}_{2} \mathrm{O}$ or kainite $\mathrm{KCl} \cdot \mathrm{MgSO}_{4} \cdot 3 \mathrm{H}_{2} \mathrm{O}$ ) usually contains a number of impurities, the most characteristic of which are calcium and magnesium compounds, less characteristic are iron compounds, sulphates and water-insoluble substances (gangue).

Aqueous solution of potassium chloride (potassium brine) is the basic material used in the manufacture of potassium chlorate and for obtaining potassium hydroxide, chlorine and hydrogen. Both of these applications require the use of a high purity potassium brine, as the concentration of the impurities introduced with this material increases during processing (both manufacturing processes use closed loop solution circulation) and leads not only to product contamination, but also to process disturbance. There is rich literature on the impact of brine impurities ${ }^{1}$. Cation exchange membrane manufacturers specify maximum permissible concentrations of alkaline earth metal ions, anode manufacturers specify maximum permissible concentrations of sulphate ions. Therefore brines, prior to being fed to electrolytic cells, must be purified.

For more than one hundred years calcium and magnesium ions have been removed by the well-known hydroxide/carbonate method employing the following reactions ${ }^{2}$ :

$\mathrm{CaCl}_{2}+\mathrm{K}_{2} \mathrm{CO}_{3} \rightarrow \mathrm{CaCO}_{3} \downarrow+2 \mathrm{KCl}$

$\mathrm{MgCl}_{2}+2 \mathrm{KOH} \rightarrow \mathrm{Mg}(\mathrm{OH})_{2} \downarrow+2 \mathrm{KCl}$

Upon separating the precipitate, the solution still contains a few $\mathrm{mg} / \mathrm{dm}^{3}$ of $\mathrm{Ca}^{2+}+\mathrm{Mg}^{2+}$, which is admissible in the manufacture of potassium chlorate and in mercury cell and diaphragm cell processes. For the membrane cell technology, however, this concentration is too high, and therefore it has to be reduced to ca. $0.01 \mathrm{mg} / \mathrm{dm}^{3}$ by passing the solution through a column filled with a cation exchange resin ${ }^{3}$. Sulphate ions are removed by adding barium chloride and precipitation of $\mathrm{BaSO}_{4}$.

While adding solid potassium chloride to a circulating brine and purifying the brine afterwards is possible (and in fact applied) in the processes of chlorine, hydrogen and potassium hydroxide manufacture, it is hardly applicable in the processes of potassium (or sodium) chlorate manufacture. Process solutions used in the manufacture of chlorates contain chromium(VI) salts at an average concentration of $5 \mathrm{~g} \mathrm{~K}_{2} \mathrm{Cr}_{2} \mathrm{O}_{7}$ or $\mathrm{Na}_{2} \mathrm{Cr}_{2} \mathrm{O}_{7}$ in $1 \mathrm{dm}^{3}$. Removing anything from these solutions by precipitation leads to the formation of precipitates contaminated with chromium compounds. Experience shows that even very careful (and technically feasible) washing of such precipitates is not sufficient enough. The precipitation of $\mathrm{SO}_{4}{ }^{2-}$ ions with barium chloride causes simultaneous precipitation of barium chromate (solubilities of these compounds are $1.15 \mathrm{mg} \mathrm{BaSO}{ }_{4} / \mathrm{dm}^{3}$ and $3.7 \mathrm{mg} \mathrm{BaCrO} / \mathrm{dm}^{3}$, respectively). Therefore brine purification is carried out prior to combining it with the circulating solutions. The removal of $\mathrm{SO}_{4}{ }^{2-}$ ions must be done before the precipitation of alkaline earth metal ions - if barium chloride is added in excess, $\mathrm{Ba}^{2+}$ ions precipitate in the form of barium carbonate. Then, however, processing of both precipitates is complicated: barium sulphate is contaminated with the gangue, and $\mathrm{CaCO}_{3}+\mathrm{Mg}(\mathrm{OH})_{2}$ precipitate, a potential lime fertilizer, contains toxic barium carbonate. Sulphate ions can be removed by nanofiltration as well ${ }^{4}$. This method was laboratory tested and applied in industry ${ }^{5,6}$.

\section{EXPERIMENTAL}

\section{New method for removing $\mathrm{SO}_{4}{ }^{2-}$ ions}

The devising of a wastefree method of potassium brine purification became possible after developing ${ }^{7}$ and applying by Kaneka Corp. of Japan of a new method of separation sulphates (NDS - New Desulphation System) with the use of zirconium hydroxide anion exchange resin. Methods for obtaining the new zirconium hydroxide anion exchanger and conditions of its use in the purification of sodium brines have been described in the literature ${ }^{\mathbf{8}, \boldsymbol{9}}$. The processes that take place during sorption and desorption are described by reaction equations (3) to (6). Sorption must be effected in an acidic environment, when anion exchange properties prevail. In an alkaline environment cation exchange properties arise. 
Acidification:

$\left[\mathrm{Zr}(\mathrm{OH})_{2}\right]^{2+}+2 \mathrm{HCl} \rightarrow\left[\mathrm{ZrCl}_{2}\right]^{2+}+\mathrm{H}_{2} \mathrm{O}$

$\mathrm{SO}_{4}^{2-}$ sorption:

$\left[\mathrm{ZrCl}_{2}\right]^{2+}+\mathrm{SO}_{4}^{2-} \rightarrow\left[\mathrm{ZrSO}_{4}\right]^{2+}+2 \mathrm{Cl}^{-}$

Alkalization:

$\left[\mathrm{ZrSO}_{4}\right]^{2+}+2 \mathrm{KOH} \rightarrow\left[\mathrm{Zr}(\mathrm{OH})_{2}\right]^{2+}+\mathrm{K}_{2} \mathrm{SO}_{4}$

$\left[\mathrm{ZrCl}_{2}\right]^{2+}+2 \mathrm{KOH} \rightarrow\left[\mathrm{Zr}(\mathrm{OH})_{2}\right]^{2+}+2 \mathrm{KCl}$

The eluate after desorption (5) and (6) comprises a solution of $\mathrm{K}_{2} \mathrm{SO}_{4}+\mathrm{KCl}+\mathrm{KOH}$, whereas the cation exchange resin traps (and releases) more $\mathrm{SO}_{4}{ }^{2-}$ ions than $\mathrm{Cl}^{-}$ions. The solution, after neutralising potassium hydrovide with hydrochloric acid or sulphuric acid, is concentrated, resulting in the crystallization of potassium sulphate ${ }^{\mathbf{1 0}}$. Potassium chloride starts precipitating when the concentration of $(285 \div 288) \mathrm{g} \mathrm{KCl} / \mathrm{dm}^{3}$ is exceeded. Therefore concentrations must not rise to more than $280 \mathrm{~g} \mathrm{KCl} / \mathrm{dm}^{3}$.

Tests ${ }^{11}$ have shown that the zirconium hydroxide anion exchanger cannot be used to purify circulating solutions in the manufacture of potassium chlorate, as in addition to $\mathrm{SO}_{4}{ }^{2-}$ and $\mathrm{C}^{\mathrm{l}}$ ions it also binds chromate ions, the latter being enhanced by the fact that it is used in excess in order to boost the removal of sulphate ions. It may, however, be used to purify potassium brine, and its application for this purpose makes the process wastefree.

\section{Purification of potassium brine in the manufacture of potassium chlorate}

A block flow diagram of the potassium brine purification process shown in Fig. 1 is described below. The numbers of the subsequent paragraphs correspond to the operation and unit process numbers in Fig. 1. The quality parameters of the products of brine purification are given in Tables 1 and 2. The material used in purification tests was a technical grade potassium chloride of the following composition: chlorides (as $\mathrm{KCl})-97.69 \% ; \mathrm{SO}_{4}{ }^{2-}-0.40 \%$; $\mathrm{Mg}^{2+}-0.46 \% ; \mathrm{Ca}^{2+}-0.55 \% ; \mathrm{Na}^{+}-0.29 \% ; \mathrm{H}_{2} \mathrm{O}-$ $0.31 \%$; water insolubles $-0.29 \%$.

1) Potassium chloride is dissolved in water. The precipitating agents, potassium hydroxide and carbonate, can be (and in fact are) added at the stage of dissolution (as shown in Fig. 1) or at a later stage to the crude brine. The precipitating agents should be added in a slight excess in relation to the stoichiometric amount determined by the reaction equations (1) and (2) and equal to no less than $0.1 \mathrm{~g} \mathrm{KOH} / \mathrm{dm}^{3}$ and $0.3 \mathrm{~g} \mathrm{~K}_{2} \mathrm{CO}_{3} / \mathrm{dm}^{3}$. In such case the total concentration of $\mathrm{Mg}^{2+}$ and $\mathrm{Ca}^{2+}$ ions in the brine does not exceed $5 \mathrm{mg} / \mathrm{dm}^{3}$.

2) The precipitate is separated by filtration and washed on the filter with water. The washings are combined with the brine. The efficiency of potassium chloride separation during subsequent operations of washing with water taken in an amount equal to the weight of the wet precipitate is presented in Table 1.

The washed precipitate is dried. The product obtained, magnesium/potassium fertilizer lime, is suitable for use by farmers and gardeners to treat acid soils without the fear of soil overalkalizing, and to enrich the soil with magnesium and potassium. Users of such lime suggest that no washing should be applied. However, at least one washing operation is recommended, as it decreases potassium chloride losses by more than $60 \%$, while still large amounts of $\mathrm{KCl}$ are retained. Suitability of fertilizer lime
Table 1. The composition (dry product basis) of magnesium/ potassium fertilizer lime as a function of the number of washing operations

\begin{tabular}{|c|l|r|r|r|r|}
\hline \multirow{2}{*}{ Lp } & \multirow{2}{*}{ Component, \% wt/wt } & \multicolumn{4}{|c|}{ No. of washing operations } \\
\cline { 3 - 6 } & & \multicolumn{1}{|c|}{0} & \multicolumn{1}{|c|}{2} & \multicolumn{1}{c|}{3} \\
\hline 1. & $\mathrm{CaCO}_{3}$ & 48.95 & 51.41 & 52.50 & 52.87 \\
\hline 2. & $\mathrm{Mg}(\mathrm{OH})_{2}$ & 39.33 & 41.31 & 42.19 & 42.48 \\
\hline 3. & $\mathrm{KCl}$ & 7.51 & 2.89 & 0.83 & 0.15 \\
\hline 4. & Water insolubles & 3.71 & 3.89 & 3.98 & 4.00 \\
\hline 5. & $\mathrm{H}_{2} \mathrm{O}$ & 0.50 & 0.50 & 0.50 & 0.50 \\
\hline
\end{tabular}

for agricultural purposes should be verified for every potassium chloride batch. Raw potassium chloride (technical grade) can vary in the composition and occurrence of the undesired components.

3) The aim of drying the fertilizer lime is to prevent its caking and maintain it in the condition enabling its spreading in the fields by means of standard farm machines.

4) The brine is acidified to ca. $\mathrm{pH} 1$ with hydrochloric acid, and the anion exchanger in powder form is added while agitating the brine. The amount of anion exchanger added should be at least $25 \mathrm{~g} / 1 \mathrm{~g} \mathrm{SO}_{4}{ }^{2-}$, preferably $30 \mathrm{~g} /$ $1 \mathrm{~g} \mathrm{SO}_{4}^{2-}$. Sulphate ions are bound at the temperature of ca. $60^{\circ} \mathrm{C}$. When the anion exchanger is added, $\mathrm{pH}$ increases. It should, however, remain in the range between 2 and 3. If necessary, more hydrochloric acid may be added.

5) The suspension is filtered. The ion exchanger should not be washed, as the resultant increase in $\mathrm{pH}$ could cause partial desorption of $\mathrm{SO}_{4}^{2-}$ ions.

6) The filtrate comprises purified and acidified potassium brine. Prior to its use in the manufacture of potassium chlorate it requires neutralizing with potassium hydroxide solution.

7) Desorption of $\mathrm{SO}_{4}{ }^{2-}$ and $\mathrm{Cl}^{-}$ions [reactions (5) and (6)] is effected with a potassium hydroxide solution taken in excess amount ( $\mathrm{pH}$ ca. 13) at the temperature of ca. $60^{\circ} \mathrm{C}$.

8), 9) The suspension of the regenerated ion exchanger is filtered, preferably on a vacuum drum filter. The regenerated anion exchanger in hydroxide form is washed on the filter and, either dried (which facilitates proportioning by weight) or not, is recycled to stage 4 - sorption of $\mathrm{SO}_{4}{ }^{2-}$ ions. Ion exchanger washing solution is combined with the filtrate.

10) The filtrate (post-reaction solution) is neutralized with hydrochloric acid. The average composition of the neutralized solution is as follows: $\mathrm{K}_{2} \mathrm{SO}_{4}-15 \mathrm{~g} / \mathrm{dm}^{3}, \mathrm{KCl}$ $-25 \mathrm{~g} / \mathrm{dm}^{3}$. Sulphuric acid can be used instead of hydrochloric acid - this way the amount of potassium sulphate can be increased, but on the other hand the amount of potassium chloride recycled to the brine is decreased.

11) The solution is concentrated by evaporation until $\mathrm{KCl}$ concentration reaches ca. $280 \mathrm{~g} / \mathrm{dm}^{3}$. Crystallization of potassium sulphate often starts at this stage.

12) The concentrated solution is cooled in a crystallizer. The suspension is then centrifuged. The filtrate, with its average composition $280 \mathrm{gKCl} / \mathrm{dm}^{3}$ and 20 to $22 \mathrm{~g} \mathrm{~K}_{2} \mathrm{SO}_{4} /$ $\mathrm{dm}^{3}$, is recycled to stage 4 . In order to separate potassium chloride the crystalline $\mathrm{K}_{2} \mathrm{SO}_{4}$ can be washed in the centrifuge. The effects of washing with water taken in an amount equal to the weight of the crystalline product in the centrifuge are presented in Table 2. 


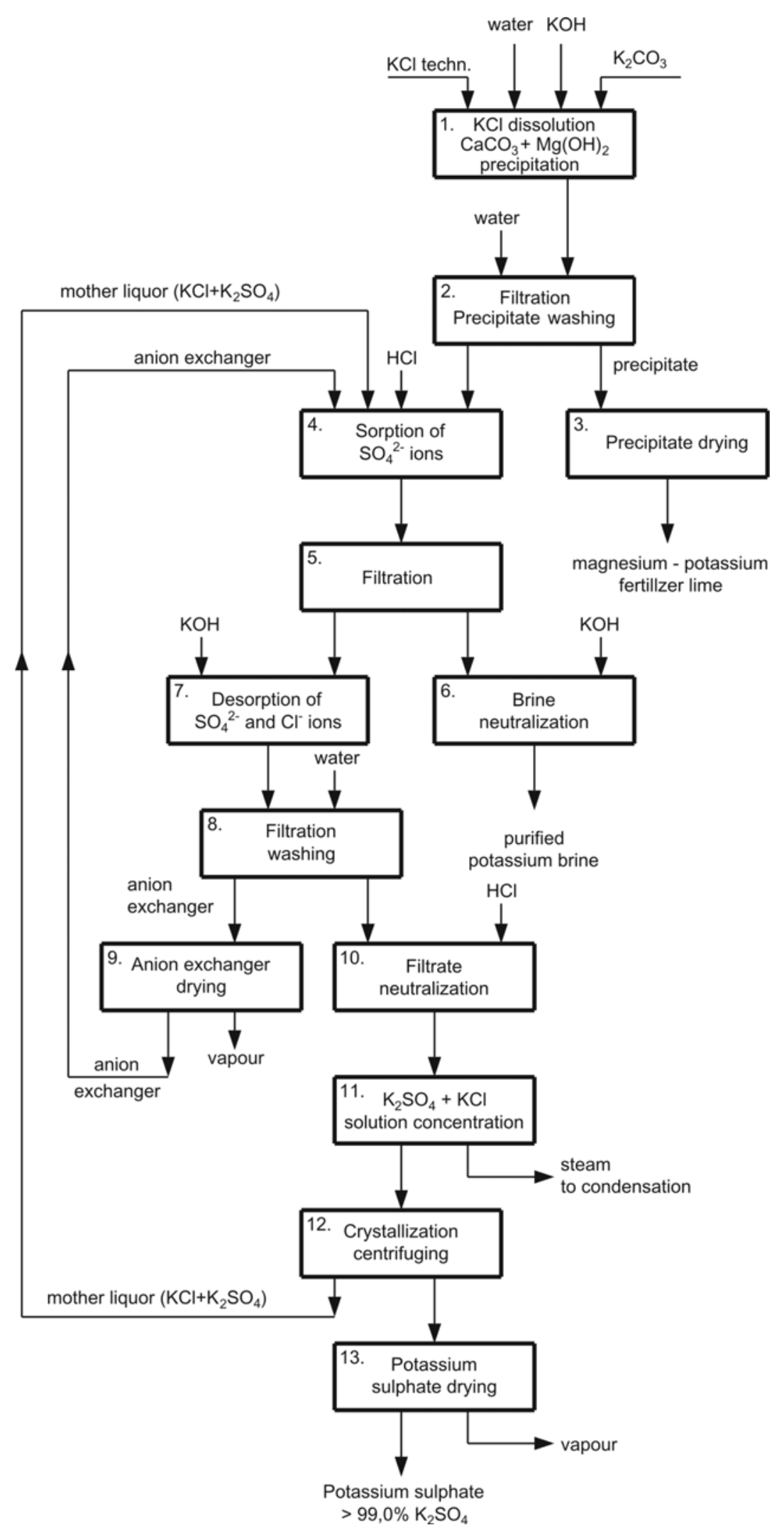

Figure 1. A simplified flow diagram of the purification process of potassium brine for the manufacture of potassium chlorate

Table 2. The content of $\mathrm{KCl}$ in potassium sulphate (dry basis) as a function of the number of washing operations

\begin{tabular}{|c|c|c|c|c|}
\hline $\begin{array}{c}\text { No. of } \\
\text { washing } \\
\text { operations }\end{array}$ & 0 & 1 & 2 & 3 \\
\hline $\begin{array}{c}\mathrm{KCl} \text { content, } \\
\%\end{array}$ & $\begin{array}{c}0.57 \text { to } \\
0.74\end{array}$ & 0.29 & 0.17 & 0.17 \\
\hline
\end{tabular}

If the potassium sulphate is to be used in the manufacture of NPK fertilizers, then washing is not necessary. It may, however, be advisable in the case of other applications. Water content in the wet crystalline product is usually 2.0 to $2.5 \%$. The purposefulness of the drying of potassium sulphate, which prevents the caking thereof, is obvious. 
The purified potassium brine is transferred to potassium chlorate manufacture and then is converted according to the known exchange reaction:

$\mathrm{NaClO}_{3}+\mathrm{KCl} \rightarrow \mathrm{KClO}_{3} \downarrow+\mathrm{NaCl}$

Sodium chloride solution, which contains some $\mathrm{K}^{+}$ and $\mathrm{ClO}^{-}$ions (also $\mathrm{Cr}_{2} \mathrm{O}_{7}{ }^{2-}$ ions), is recycled to electrolysis in order to obtain sodium chlorate. After electrolysis the solution is recycled to reaction (7). This solution is not subjected to purification, unless specially required.
Purification of potassium brine for the manufacture of $\mathrm{KOH}+\mathrm{Cl}_{\mathbf{2}}+\mathrm{H}_{\mathbf{2}}$ by the membrane method

The method of potassium brine purification described here may find application in the preparation of a solution for the manufacture of $\mathrm{KOH}+\mathrm{Cl}_{2}+\mathrm{H}_{2}$ by the membrane method. While the principle remains the same as above, some modifications must be implemented. A simplified flow diagram of the purification process of the brine for the membrane electrolysis is presented in Fig. 2.

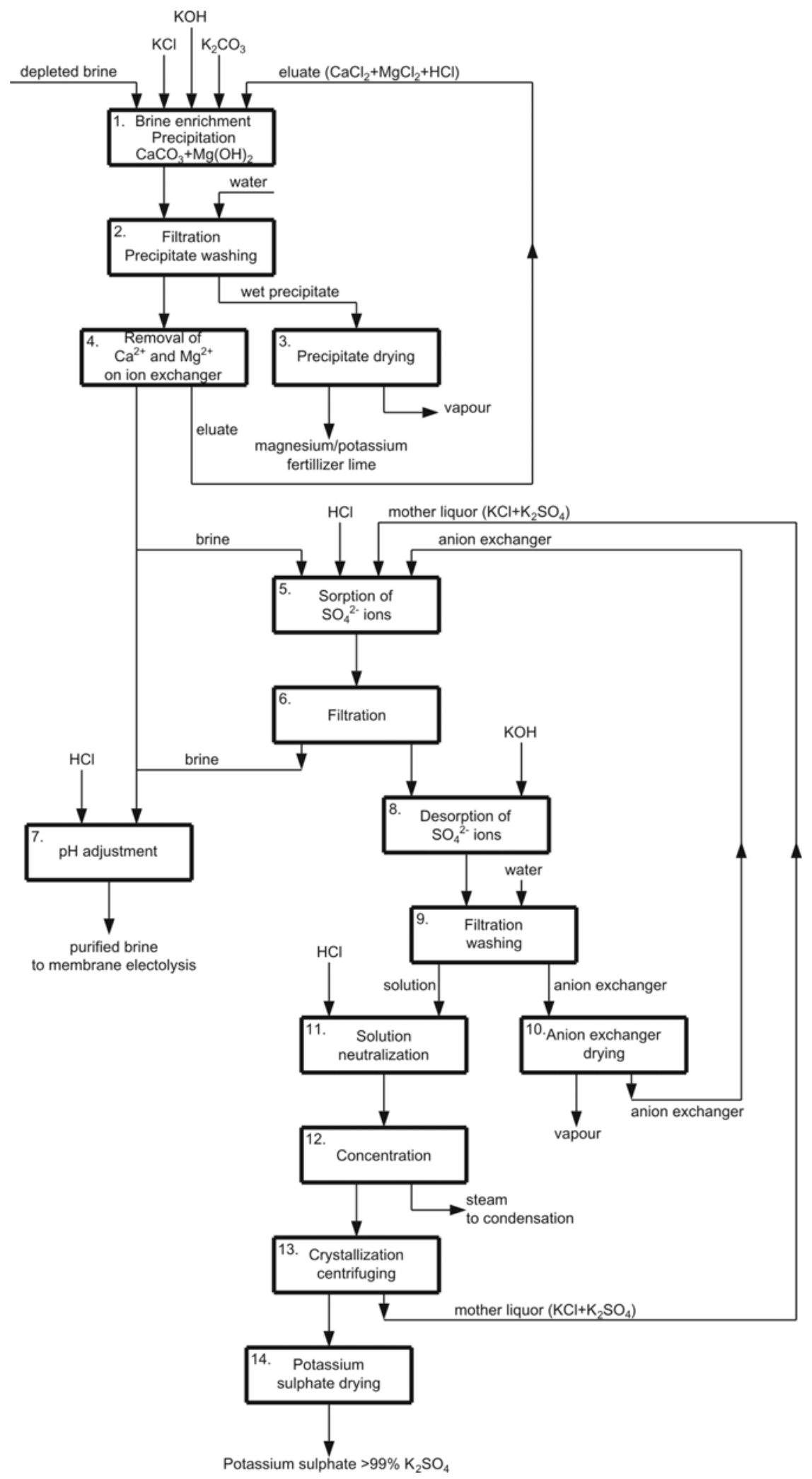

Figure 2. A simplified flow diagram of the purification process of potassium brine for the manufacture of $\mathrm{KOH}^{+} \mathrm{Cl}_{2}+\mathrm{H}_{2}$ by the membrane method 
The description given below focuses on the differences in relation to Fig. 1.

In the membrane process the brine circulates in a closed loop system. Solid potassium chloride is added to the depleted brine (after electrolysis). At this stage the acidic eluate, which contains $\mathrm{CaCl}_{2}+\mathrm{MgCl}_{2}+\mathrm{HCl}$, is fed from the ion exchanger regeneration process. This way the eluate, instead of being a troublesome waste, becomes an additional source of $\mathrm{Ca}^{2+}$ and $\mathrm{Mg}^{2+}$ ions for the fertilizer lime, while the chloride ions are recycled to the brine.

1) and 2) Filtration, precipitate washing and drying, leading to the magnesium/potassium fertilizer lime, are similar to those described for the preparation of brine for the manufacture of potassium chlorate.

3 ) The second stage of purifying the brine of $\mathrm{Ca}^{2+}$ and $\mathrm{Mg}^{2+}$ ions in ion exchange columns is based on known processes. The concept presented in this paper does not imply any modifications. The eluate from ion exchanger regeneration is recycled to stage 1 .

4), 6) and 8) to 15) These stages have the same features as those described above, with one exception being that only part of the stream is purified of $\mathrm{SO}_{4}^{2-}$ ions. The permissible concentration of $\mathrm{SO}_{4}^{2-}$ ions specified by anode manufacturers is between 5.0 and $7.5 \mathrm{~g} / \mathrm{dm}^{3}$. To maintain the concentration below this limit it is sufficient to purify only 10 to $20 \%$ of the brine. The use of zirconium hydroxide anion exchanger allows reducing the percentage of the purified brine in the entire brine stream because it removes ca. $99 \%$ of sulphate ions without contaminating the solution with any undesired substances.

7) The brine after removal of $\mathrm{Ca}^{2+}$ and $\mathrm{Mg}^{2+}$ ions is alkaline, whereas the brine after the removal of $\mathrm{SO}_{4}{ }^{2-}$ ions is acidic. Upon combining those two streams, $\mathrm{pH}$ adjustment is necessary, that is acidification to $\mathrm{pH} 2$ to 3 , as required for membrane electrolysis.

\section{CONCLUSIONS}

The method of purifying potassium brine presented here has been entirely tested on a large laboratory scale. The suitability of the $\mathrm{CaCO}_{3}+\mathrm{Mg}(\mathrm{OH})_{2}+\mathrm{KCl}+$ gangue mixture for the use as fertilizer lime has been confirmed. It therefore may be assumed that, in principle, the process is wastefree.

\section{ACKNOWLEDGEMENT}

This paper is part of Development Project No. R05 00302 funded by the Polish Ministry of Science and Higher Education.

\section{LITERATURE CITED}

1. Tanaka, Y. (2007) Electrochemistry. In Ion Exchange Membranes - Fundamentals and Applications. Ch.5 (pp. 461 - 485). Membrane Science and Technology. Elsevier B.V. DOI:10.1016/S0927-5193(07)12019-2.

2. Bohr, R., Rausch, M. \& Schlidhauer, R. (1999). EP Patent No 995,719.

3. Muraviev, D., Noguerol, J. \& Valiente, M. (1996) Separation and concentration of calcium and magnesium from sea water by carboxylic resins with temperature-induced selectivity. React. Funct. Polym. 28 (2), 103-220. DOI:10.1016/13815148(95)00046-1.
4. Twardowski, Z. \& Ulan, J.G. (1999). U.S. Patent No $5,858,240$

5. Bessarabov, D. \& Twardowski, Z. (2002). Industrial application of nanofiltration - new perspectives. Membr. Technol., 9, 6-9, DOI:10.1016/S0958-2118(02)09017-1.

6. Barr, A. (2001). Sulphate removal by nanofiltration. Filtration \& Separation 38 (6), 18 - 20, DOI:10.1016/S00151882(01)80376-1.

7. Saiki, K., Yoshida, N., Kinoshita, Y. \& Kumagai, I. (1995). New Desulfation System for Chlor Alkali Plant. In Modern Chlor Alkali Technology, Vol.6, Ch.8 (pp. 82 - 88). London, Ed. R.W. Curry.

8. Kaczmarek, T., Kwiecień, J., Mateńko, H. \& Sołtysik, B. (1996) Opracowanie sposobu odsiarczania zasolonych wód kopalnianych z KWK „Jaworzno" na adsorbencie nieorganicznym. (Development of a method of desulphating saline mine waters from the Jaworzno Coal Mine using an inorganic adsorbent). Report of the Institute of Inorganic Chemistry in Gliwice No. 4019, unpublished.

9. Cichy, B. \& Kwiecień, J. (2000) Opracowanie technologii wytwarzania anionitu do usuwania jonów siarczanowych. (Development of a process for obtaining an anion exchanger for the removal of sulphate ions). Report of the Institute of Inorganic Chemistry in Gliwice No. 4201, unpublished.

10. Sedell, A., Linke, W.F., Francis, A.W. \& Bates, R.G. (1952) Solubilities of Inorganic and Organic Compounds. New York, USA, D.Van Nostrand Co. P.284.

11. Pisarska, B. Badania i opracowanie założeń technologicznych do projektu procesowego kompleksu produkcyjnego, obejmującego chloran sodu, chloryn sodu, chloran potasu i podchloryn sodu (Research on and drawing up of process specifications for a manufacturing system comprising sodium chlorate, sodium chlorite, potassium chlorate and sodium hypochlorite) - Development Project No. R05 003 02, in Progress. 